\title{
Breast Fluid or Secretion
}

National Cancer Institute

\section{Source}

National Cancer Institute. Breast Fluid or Secretion. NCI Thesaurus. Code C13401.

Any of the secretions of the breast. 